\title{
Construction of China's Agricultural Virtual Logistics Information Service Platform
}

\author{
Hanbin Wang \\ School of Business and Information Technology \\ Quanzhou Normal University \\ Quanzhou, China \\ wanghanbin@qztc.edu.cn
}

\author{
Meiqin Liu \\ School of Business and Information Technology \\ Quanzhou Normal University \\ Quanzhou, China \\ 649047197@qq.com
}

\begin{abstract}
Most of the agricultural products in China logistics enterprises still adopt the traditional business model. The efficiency of Logistics operation is low and agricultural loss is large. It is difficult to adapt to the need of modern market economy. So logistics enterprises urgently need to implement information management. Virtual logistics information service platform is applied to implement enterprise information management. According to the connotation of the virtual logistics of agricultural products, we can make a new definition of the virtual logistics agricultural products. Starting from the present situation of virtual logistics of agricultural products in our country, we need to analyze the problems that exist in the virtual logistics of agricultural products. The page combines the characteristics of agricultural products logistics and virtual logistics operation mode. And we build the operating models of virtual logistics information service platform of agricultural products, and it is put forward the countermeasures.
\end{abstract}

Keywords-the logistics of agricultural products; virtual logistics; information services platform

\section{THE DEFINITION AND CONNOTATION OF THE VIRTUAL LOGISTICS OF AGRICULTURAL PRODUCTS}

Virtual logistics of agricultural products is multiplied with complementary resources, including agricultural production, technology, management and member enterprises engaged in logistics, business flow. So that we can realize the resource sharing, risk sharing, complementary advantages and other characteristics of the strategic objectives. So as to realize the agricultural market opportunity, rapid response, improve the participation enterprise of virtual logistics organizations and efficient cooperation. Agricultural products supply chain is the body of the virtual logistics of agricultural products, including all participants .The virtual logistics of agricultural products is based on computer network and database technology. The network as a distribution center and then the virtual connection, will organize buyers and sellers in a timely manner, and complete information to agricultural products from the supplier to receive the logistics activity. Virtual logistics of agricultural products is to improve the rapid response of the market and explore the market. So that we can develop the added value of agricultural products, and cut down the cost of circulation of agricultural products. [1].

Above all, I think virtual logistics of agricultural products is based on network, and combined with modern information and communication technology as the main means of communication, cooperation innovation, and common development for agricultural products. Its information from the supplier is related to the enterprise or organization in the virtual space of dynamic alliance.

II. THE ANALYSIS OF THE PRESENT SITUATION AND THE EXISTING PROBLEMS OF AGRICULTURAL PRODUCTS LOGISTICS IN CHINA

\section{A. The Status Quo of Agricultural Product Logistics iIn Our Country}

1) The total cost of the logistics of agricultural products. Agricultural logistics products amount is increasing each year. The proportion of total logistics has always been in decline, Compared with the proportion of the first industry in our country. In 2011, our country agricultural products logistics is totaled 2.336098 trillion Yuan, up $4.5 \%$ from a year earlier. Agricultural product logistics in our country present growth amount has been eight years in a row. However, the proportion of total social logistics has been a declining trend, only $1.47 \%$ in 2011.Our country agricultural product logistics is relatively backward.

2) Logistics scale of agricultural products. Our country is an agricultural big country. Natural geographical conditions determine its agricultural product variety. In 2010, the main food production increased dramatically, total grain output of 546.41 million tons, a year-on-year increase of 15.59 million tons, the production increase $2.9 \%$, reversing the situation of food production declines year by year. A few years ago, in 2011 the national grain output reached 571.21 million tons, more than 2010 annual output 24.8 million tons, an increase of $4.5 \%$. Most of the rest goods need logistics formed a lot of agricultural products logistics and that is also constantly expanding. 
3) The industrial chain of agricultural products. Agricultural product processed from agriculture, makes our country agriculture into the low yields only provide raw materials and primary products industry, agricultural self accumulation and self improve is weaker. For now, people in the United States food consumer spending is $80 \%$ after use in agricultural production, wholesale and retail of centralization or decentralization, transportation of agricultural products, agricultural products processing, advertising, the cost of agricultural products packaging, catering services and so on, and our country in this respect it is woefully inadequate.

4) The safety of the food system. In food processing, storage, transportation and sales process, due to the raw material is not completely by environmental pollution. Bacteria killing, storage and transportation method are not correct. The health is caused germs and bacteria are important. The current logistics of agricultural products is closely related. It puts forward higher requirements for China's agricultural products logistics.

5) Sales channel network of rural commodity. In recent years, agricultural materials industry achieved rapid development in our country. Fundamental changes in market supply and demand condition, circulation development has preliminary formed. Currently enterprises have nearly thousand of agricultural materials chain, chain stores in more than 30000.

6) The infrastructure construction in rural areas and agricultural products logistics. Agricultural products circulation of tolls accounted for about $15 \%$ of the cost to $20 \%$.Fujian province every year from a farm transport vehicle is about 100 million Yuan. Sichuan province in 2004 opened the green channel. The second time just marketing of fresh agricultural products vehicle is doubled. It is estimated that sales are nearly 10 million tons of agricultural [2].

\section{B. The Problems of China's Agricultural Products Logistics}

1) The single distribution channels of agricultural products. The bulk logistics of agricultural products in China often need to go through this link: Producer origin market a marketing wholesaler sales market retailers, consumers, without manufacturing sales of fresh agricultural products occupy a large part. There is no way to adapt our agricultural products sold fresh form. So because of the tariffs, capacity, traffic conditions, preservation of agricultural technology and other reasons caused huge losses. The vast majority of farmers can not get the profits of value-added agricultural products in the circulation process.

2) Higher logistics costs. The high cost of logistics of agricultural products in China, value-added capability is weak. The survey shows that domestic food shipped from the production area to the money spent by the sales area, accounting for $30 \%$ to $35 \%$ of food sales prices. China's grain logistics enterprises to the distribution cost more than $10 \%$ higher than their foreign counterparts, with the same market competition. 60\% Fresh products accounted for about $60 \%$, or even more. Among them, the agricultural development of the United States, Japan, Canada and some agricultural products are below the price of production of agricultural products in China.

3) Logistics and technical level is too low. Serious lack of cold chain logistics in China lags behind compared to other countries mainly reflected in the professional transport equipment. Refrigerated trucks are only about $2 \%$ of the total number of the railway. There is no standard insulation, preservation transport cars. The number of transport is actually less than the total of railway freight transport.

Modern refrigerated trucks are also serious lack of refrigerated and insulated vehicles share is very low, only $0.3 \%$ of the proportion of goods transports vehicles. In developed countries, the United States is $1 \%$, and $2.6 \%$ in the United Kingdom, Germany has reached 3\%. In addition, the lack of professional refrigeration equipment such as freezer actually leads to a key reason behind China's cold chain logistics.

4) weak agricultural logistics information. China's agricultural information network is often a gap in the township, coupled with the quality of the farmers. Our farmers can not go to production needs from the market. At present, China has begun to build agricultural information platform. The cultural level of farmers has led to the usage of information platform which is not high. [3] In the United States, $85 \%$ of the farmers can search in the Internet. $16 \%$ of the farmers are engaged online to purchase a business.

\section{THE VIRTUAL LOGISTICS INFORMATION SERVICE PLATFORM IN AGRICULTURAL PRODUCTS}

Agricultural Products Logistics is essentially the use of information technology. To build a farm co-op, fourth party logistics, third party logistics, sales of agricultural products business cooperation network, the value of agricultural products brought into full play, achieving the goal of the members of the Union to obtain excess profits. The key to achieving this goal is to establish agricultural products of an Internet-based virtual logistics information platform.

\section{A. The Needs Analysis of Agricultural Products the Virtual Logistics Information Service Platform}

Establishment of agricultural virtual logistics information platform aims to carry out scientific agricultural supply chain e-commerce, agricultural Virtual Logistics Alliance organization, management, coordination. Agricultural the virtual logistics information service platform should meet the following requirements: 
- $\quad$ The supply of agricultural products and vendors in Agricultural Association show demand for agricultural products, the query;

- Core third-party logistics enterprises in a show of strength on the platform self;

- The futures trading of agricultural products and agricultural products logistics services;

- To carry out e-commerce meetings, including auction features in the platform;

- On the state of agricultural logistics real-time query, Member logistics enterprises, business-like, and read to be synchronized updates;

- Customer management functions, including customers online login, password changes, rating level, digital certification, membership information, tenders online delivery;

- Entrance landing administrator from the background, to carry people along with video conferencing, the handling of tenders, the virtual logistics partner selection, real-time intelligence of the entire logistics chain optimization;

- The agricultural industry, logistics industry news and information show;

- Agricultural knowledge, logistics knowledge collection, sorting, display, carry out agricultural products, logistics forum;

- $\quad$ Save the user's resources to facilitate user access; system to be safe and reliable;

The entire information service platform should have openness, standardization, modularity. Adaptability characteristics should be as compatible as possible to the core logistics enterprise information platform system..

\section{B. The Service Object Agricultural Products in the Virtual Logistics Information Platform}

Agricultural products the virtual logistics information platform services, include farm co-op, fourth party logistics companies, third-party logistics enterprises, vendors, farmers, intermediary organizations, leading enterprises, rural areas.

From the trading behavior of the main agricultural products logistics point of view, the farmers do not have the ability to collect the information of the logistics providers. There is no way to generate economies of scale, relative to logistics providers at a disadvantageous position. Agricultural cooperation as one of the market players, representing the interests of farmers, is the starting point for Virtual Logistics Alliance of agricultural products. It formed a strategic partnership with logistics providers.

\section{Operation Mode of Agricultural the Virtual Logistics Information Service Platform}

Management information system platform mode can be divided into four kinds: the host terminal mode (single version), file server mode, client / server mode (Client / Server, referred to as the C / S) and a Web browser / server mode (Browser / Sever. referred to as the B / S). C / S and $\mathrm{B} / \mathrm{S}$ are the most widely used of the two mainstream models. The main difference between the $\mathrm{C}$ and $\mathrm{S}$ is a fat cline. Install the client application requires the user to access the computer. $\mathrm{B}$ / $\mathrm{S}$ is a thin client, only requires the user to have a computer to open the page that you can log in using the system.

The structure of the agricultural products the virtual logistics information platform has four layers:

- Agricultural virtual logistics information platform resources layer: including physical resources and logical resources, physical resources, including memory, network, computer, instrumentation and information security infrastructure, etc

- The agricultural virtual logistics information platform external interface layer: external interface layer provides resource management, data management, network security.

- Agricultural virtual logistics information platform services layer: including a variety of services related to the functions of the virtual logistics hub. Receiving a user of the service layer network service request, analyzes the processing request to provide to meet the requirements of the service, the core network service.

- Agricultural virtual logistics information platform applications layer: utilization of network resources provide the necessary application, including the user directly to network services using a graphical interface, command line interface and the program to access the API function. Grid internal structure and operation hides the complexity of the user-friendliness of the use of grid services.

The Structure and Function of the Information Service Platform

The entire agricultural logistics information service platform is divided into the following four-story, its structure and functions are as follows:

1) The basic information platform database, the standard library and case base. Basic information platform database has the standard library and case base level of quality of agricultural products, insurance; food safety standards regulate cold storage management regulations.

2) Platform management and coordination, information platform on the day-to-day management, maintenance and application coordination function. Platform management coordination and information platform on the day-to-day management, maintenance and application of coordination features include user management, interface management, transaction management, message management, management, security management, operation monitoring and resource scheduling.

3) An external interface layer. External interface layer includes central logistics business logistics systems, agro-processing enterprise systems management, government management system and other external systems. The logistics supply chain of agricultural 
products in the form of the enterprise information can be agent virtual logistics information platform.

4) Project management. Project management including e-commerce environment, mainly produce the Virtual Logistics program design, logistics management, entity project evaluation and a series of logistics supply chain. The system features include: data exchange information system, e-commerce conference, agricultural products processing plant, cold storage, transport vehicles online booking, logistics tracking, online payment, and online insurance, automatically cleared.

In order to achieve the above functions, such as a sudden need support system:

a) Physical logistics operation system: Agricultural logistics supply chain process operating system should include: the agricultural procurement management system, management system, production and processing of packaging and transportation scheduling system, freight forwarders, warehouse management system, intelligent power distribution management system and logistics enterprises commonly used basic logistics of the operating system.

b) Exchange the data subsystem: Electronic document exchange system provides e-commerce environment, network data exchange service provides a standard, low cost data exchange between the agricultural supply chain partners.

c) Digital authentication system: Digital certification system is the economic development of the era of ecommerce network system. The use of encryption and decryption technology gives different weight limits. The computer and the Internet-based information exchange establish a connection between the virtual information platform partners to protect the security of agricultural virtual logistics partner information and data exchange channel.

d) Online payment system: The use of third-party payment platform is the standard behavior between the virtual partners, to avoid disputes.

e) Customs system: China's agricultural products are often exported to South Korea and other countries. The customs has become an indispensable part of the design of the logistics information platform, which will be deemed to establishment and clearance system.

f) Contract Management Information System: Customer service contract is a contract on the basis of a business. On this basis, allocate resources, monitoring the implementation of results and accounting costs [4].

\section{The Operation of the Process of Agricultural} Information Platform

Phase I: Identify tasks. Farm co-op will be linked to the agricultural information to the virtual logistics information platform, vendor's response (or vendors will demand information linked to the agricultural co-response information platform), jointly determine the quality and flow of logistics.

Farmers to sell agricultural products to farm co-op, farm co-op linked to the Harmonized Commodity information platform, cost savings, there are economies of scale.

Phase II: Fourth choice. Have the ability to choose the fourth party logistics company logistics destination.

Stage III: establishing the agricultural logistics objectives and the formation of agricultural virtual logistics chain. 4PL 3PL

Phase IV: the physical logistics operation. 4PL Start running physical logistics, 4PL tracking the entire logistics process, and unexpected events handling, and coordinate cooperation among the members.

Fifth stage: the task is completed and liquidation. The evaluation of this logistics quality re-examine the existence of uncoordinated logistics factors, so the processed data entered into the database.

Stage 6: Union adjustments prepare for the logistics of the next period.

Agricultural products virtual logistics information platform applications countermeasures.

\section{ENHANCE THE LOGISTICS AND TECHNICAL CONTENT OF AGRICULTURAL PRODUCTS}

\section{A. Building Coverage of a Wide Range of Agricultural Products Cold Chain Logistics Network}

Mass production is more difficult to transport perishable, and other characteristics, according to the natural conditions and socio-economic conditions, seasonal, regional stability are poor. Therefore, the virtual construction of the logistics system of agricultural products, agricultural products must be performed by transport, corrosion preservation, processing, packaging, distribution. The huge losses of the primary production are a huge potential food safety. Cold chain logistics is the core of China's agricultural products logistics industry upgrade.

\section{B. Promote the Construction of the Logistics of Agricultural Products}

- We can build a real-time agricultural logistics information collecting system.

- Establish contact with the agricultural supply chain upstream and downstream customers to exchange information platform. Through the exchange of information platform for business data exchange, it can release information and logistics of agricultural supply and demand information. Post purchase order requirements.

- Build a establishment of a reasonable database system. Through the establishment of a database, you can analyze the agricultural supply chain upstream and downstream customers running data management.

- Strengthen the construction of agricultural information standards. There is no uniform standard, so that the information can not be unified, resulting in the 
flow of information and the construction of a waste of money [5].

\section{Improving the Infrastructure of the Agricultural Products Logistics}

Agricultural products logistics infrastructure, including the construction of agricultural service channel network infrastructure of roads, railways, airports, ports, logistics park, logistics node station clusters and logistics information platform. Poor infrastructure has become the biggest bottleneck of agricultural products logistics industry upgrade in China. It must find ways to improve the processing of agricultural products, storage, transportation and other infrastructure construction [6].

\section{ACKNOWLEDGMENT}

This research was supported by the funds from: Foundation item 1 : Construction Funds of Master Degree Awarded Unit of Quanzhou Normal University; Foundation item 2: Fujian university key project construction service routines "The port logistics information platform construction, Haqixi prefecture",
Project Number: A103; Foundation item 3: Science Plan Project of Quanzhou, Project Number: 2012Z109, 2012Z124; Foundation item 4: Science Plan Project of Fujian "Research of cycle development mode of Fujian agricultural processing industry - Quanzhou for Example".

\section{REFERENCES}

[1] Li Bizhen. The virtual agricultural products logistics model and its benefit-risk [J]. Development Research, 2009 (02):1-2. (in Chinese)

[2] Households' effected factors in vertical coordination. Present Situation and Countermeasures of China's agricultural logistics [J]. Agricultural Sciences, 2008 (07):1-2. (In Chinese)

[3] Liwan Qing ecological and economic plight of China's agricultural products logistics and industrialization path [J]. 2010 (07):2-3. (in Chinese)

[4] Yi Xiaoping of China's agricultural Virtual Logistics Collaboration System [D]. Qufu Normal University, 2009. (in Chinese)

[5] Articles of Kay China's agricultural products logistics information and Countermeasures [J]. Logistics Technology, 2010 (Z2):2-3. (in Chinese)

[6] Liwan Qing ecological and economic plight of China's agricultural products logistics and industrialization path [J]., 2010 (07) :2-3. (in Chinese) 